\section{PARK GÜELL: RECONSTRUCTING THE TEMPLE OF JERUSALEM THROUGH LIGHT AND AESTHETIC GEOMETRY}

\begin{abstract}
Was ist das Heiligste? Das, was heute und ewig die Geister, tiefer und tiefer gefühlt,
\end{abstract} immer nur einiger macht.

J.W. Goethe
After visiting Park Güell many times, and reading almost all that has been written on it, I have become aware that there are some issues that remain unresolved. I mean questions such as: Why does the Nature Square have the width and the length dimensions it has? What are the reasons for the position of the four sun medallions in the Hypostyle Room? How can we explain the contrast between the dynamic undulating bench and the static stone wall in Nature Square? What is the meaning of the inscriptions ded-icated to Virgin Mary that are engraved in the ceramic of the undulating bench...? In this paper, I will shortly present the series of steps necessary to take in order to answer such questions.

\section{Rediscovering the set at the end of the sloping portico}

Among the many elements that compose Park Güell, there is one that has so far gone undetected and that, in my opinion, is a key component to understand this work. This element is at the end of the Laundry Room Portico. The last three straight columns of the arcade have different features to all others: the first one has a caryatid shape that represents a washerwoman, the second is formed by curved lines, and the third by straight lines; these last two being the only ones in the entire porch that are completely symmetrical. After the last column, there is a lower stone wall, and on the other side, stairs that communicate the Hypostyle Room and the Nature Square. With this, apparently this portico is finished; but if you study this final area at length, you will see that there are more things. Thus, on the other side of the wall, supported on a stair landing, we find
MATÈRIA, núm. 16-17, 2020, ISSN 1579-2641, p. 171-198

Recepció: 27-5-2019 Acceptació: $3-2-2020$ 
1 Kin $7: 15-23 ; 2$ Kin 11:13, 23:3; and Ezk 40:48-49.

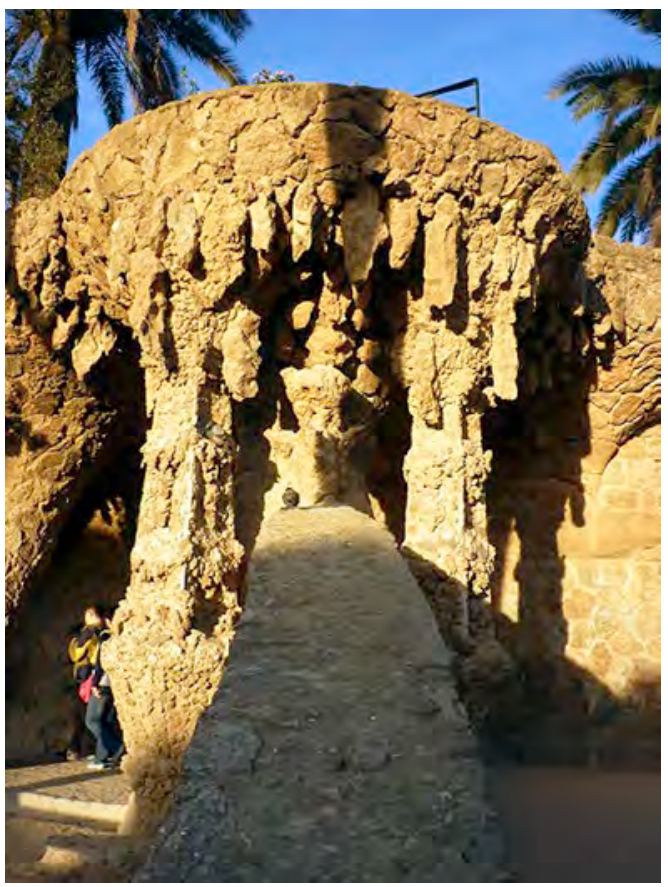

Fig. 1. The set at the end of the Laundry Room Portico, seen from where the Hypostyle Room is located. another straight column equal to the last one of the porch; and above the wall there are four stones: one is oval shaped and in vertical position; and the other three are sharp and arranged horizontally, two towards the straight columns, and the third in a straight line with the wall. In other words: we can understand that the Laundry Room Portico ends with two equal straight columns and a wall between them. In this way, what we have at the end of the sloping porch are not two spaces separated by a wall, but a group of stones between two spaces: a set that fulfils a bilateral symmetry and that could have its own meaning. Below I want to present a more careful study of this compound, to which from now on I will refer as the set at the end of the sloping portico or the set.

From the viewpoint of the history of religions, the image of two equal columns located side by side and equidistant from a central axis is associated with the Temple of Jerusalem, which, as it is explained in the Bible ${ }^{1}$, had two pillars flanking its entrance, called Jachin and Boaz. These pillars had some traits that are also fulfilled by the two columns of the set of Park Güell: to have a spherical capital, and to be oriented to the north and the south. However, the entrance to the Temple of Solomon was in the east, and from there the diverse rooms were distributed in the west direction, while behind the two columns of Park Güell there is only the end of the portico. Therefore, these two columns of the set can hardly represent the entrance to a Solomon's Temple located at Park Güell. Nevertheless, if we relate the set with the history of culture, we will find a representation that fits better. Thus, one of the interpretations of the Jachin and Boaz pillars of Solomon's Temple has consisted in making them a symbol of an association, the freemasonry. In this group, the image of the pillars Jachin and Boaz, along with other elements such as a square, a 
compass, and the letter "G" - which means God or Geometry - have become the symbol of the temple of the lodge, that is, the real space where the members of the secret society can work to overcome the tests until reaching the level when they can picture the Temple of Solomon. ${ }^{2}$ In masonry, this symbol usually appears represented along with the lodge room in the background, which is positioned inversely to Solomon's Temple, i.e., from west to east. So we could interpret the set of Park Güell as if it were a representation of the two pillars of a masonic temple that would be in the direction of the Hypostyle Room. But in this case we should find out exactly where this temple is.

\section{The cult image of the Doric Temple}

To determine where this temple is located, we have two elements found while analysing the four stones between the two columns of the set, namely: the geometry alluded to by the square and the compass reproduced, and the direction pointed to by the central stone that is placed horizontally. We will start studying the last element, to find out if any place is actually aimed at. To begin with, if we take some plans of Park Güell, and from the point that corresponds to the place where the central stones of the set are, we draw a straight line that goes eastwards, we will see that this line follows a row of columns that diagonally crosses the whole Hypostyle Room, but that it does not pass through any of the solar medallions, and that all the columns implied are exactly equal. Yet in relation to the layout of columns and solar medallions, one can realize the following. If on the line drawn we begin to count from the column closest to the set, we will see that column number six is located in the middle of both: a horizontal row that goes from Güell House to Gaudí House, and a vertical row that goes from the side of the park entrance to the side of the stone wall at the background of the Doric Temple. ${ }^{3}$ What is more, this column is also number six starting to count from the four angles of a square we could form if we added ten columns in both sides of the front part of the temple. To put it another way: this sixth column is the central point of the implicit geometric shapes on the surface occupied by the Hypostyle Hall. So, from this viewpoint, we really can state that the line we have drawn from the set at the end of the sloping portico, has taken us to a significant place.

However, although this sixth column is the central point of the implicit geometry in this space, it is not the centre from which their stellar medallions are arranged, which are the main figurative representations of this space. And to overcome this difficulty, we can resort to the other ele-
2 Juan Carlos DAZA, Diccionario Akal de la Francmasonería, Madrid, Akal, 1997, p. 87-88; Francisco ArIzA, Masonería: símbolos y ritos, Barcelona, Symbolos, 2002.

${ }^{3}$ It is true that from this stone wall to the sixth column one can only see five columns. But if you examine this wall, you will realize that its upper part curves inward, and that in the ceiling there is another row of cupolas. So it seems as if behind the stone wall there were a last horizontal row of columns, of which only the two lateral pillars were visible. 
${ }^{4}$ G. S. KIRK and J. E. RAVEN, Los filósofos presocráticos, Madrid, Gredos, 1979, p. 356357.

5 Plato, Meno, 80d-86c; Timaeus, 34c-36e, and 53c-56d.

6 Daniel Stolzius von StolZENBERG, Chymisches Lustgärlein, 1624, plate XCVIII.

7 For a more detailed account of the life and work of Peter Lenz, see: Carles Rius, Antoni Gaudí: Casa Bellesguard as the Key to His Symbolism, BarceIona, University of Barcelona, 2014, p. 45-83. ment found in the set. geometry. Thus, using the square and the compass, we can convert this sixth column into the centre of a square, a circle and an equilateral triangle:

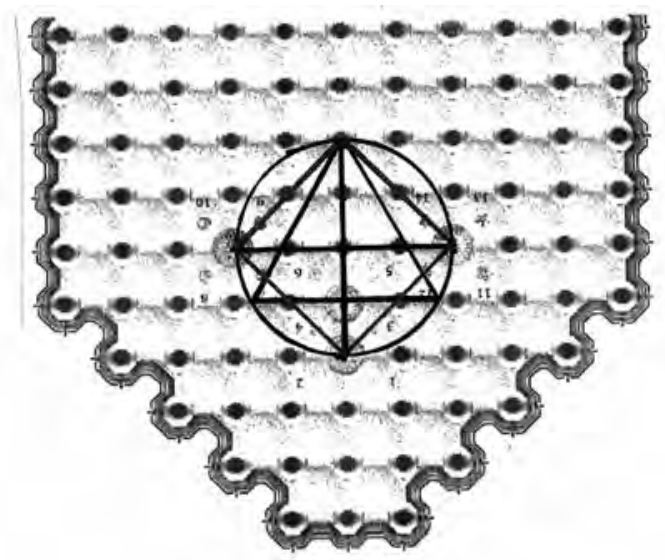

Fig. 2. The forms drawn at the Hypostyle Hall, from its central column and the solar medallions.

With this image, we have managed to make the sixth column also the centre of the implicit geometric shapes in the layout of the stars of the Hypostyle Room. And this is not any form, since philosophers such as Pythagoreans ${ }^{4}$ and Plato ${ }^{5}$, and thinkers on alchemy such as Daniel Stolcius von Stolzenberg 6 have presented a similar figure by attributing philosophical meaning to it. In addition, there is another author contemporary with Gaudí who also worked with this figure: Peter Lenz (1832-1928), a German artist that in 1895 created the Beuron School of Art, from which a group of artists emerged that painted several churches and monasteries across Europe. ${ }^{7}$ Throughout his career, Lenz also worked on a theoretical aspect: a kind of mystical geometry that he called aesthetic geometry, and which now I would like to present briefly.

Peter Lenz stated that aesthetic geometry consists in reconstructing the language God used to create the world. This language has three basic components, each one representing a person of the Holy Trinity: the square $=$ the Father, the triangle $=$ the Son, and the circumference $=$ the Holy Spirit; so that the three together - as in the figure inferred in the Doric Temple of Park Güell - would express the Holy Spirit as such. Lenz called this figure the key of God (der Schlüssel-Gottes), since he considered that from it other forms of the divine language could be reconstructed, until reaching the most complete one, the so-called sphere of the five regular solids, a luminous sphere containing the five solids, which Lenz ordered 
following the sequence dodecahedron, cube, octahedron, tetrahedron and icosahedron. Using these tools, God created Adam and Eve. But with the Fall, this language degenerated, expressing itself incompletely in some ancient temples. And yet, when Christianity arrived, once again this geometry manifested itself splendidly. ${ }^{8}$

All in all, it is likely that the figure inferred in the temple of Park Güell represents the original form (Urform) of the Creation: that which the ancients had applied to their works, that alchemical thought related to the search for the philosopher's stone, and that Peter Lenz geometrically settled within the framework of Christian Theism, calling it the key of God. In Park Güell, this figure would be the cult image of the Doric Temple, from which the profuse creativity expressed in this work would emerge. However, most authors who previously treated this figure considered it the starting point from which other more complex figures could be created. Therefore, we can assume that also Antoni Gaudí alluded to this form in Park Güell to suggest that other more elaborated ones were produced. And this is what we will try to do next.

\section{First applications of aesthetic geometry}

In order to develop more complex figures, Peter Lenz begins drawing, in the interior of the circumference of the key of God, a second equilateral triangle but inverted in relation to the first one, forming a hexagram; and from this first star, he creates other larger hexagrams. Well, if in the centre of the Doric Temple of Park Güell we follow the same procedure to draw four larger six-pointed stars, the result will be the following:

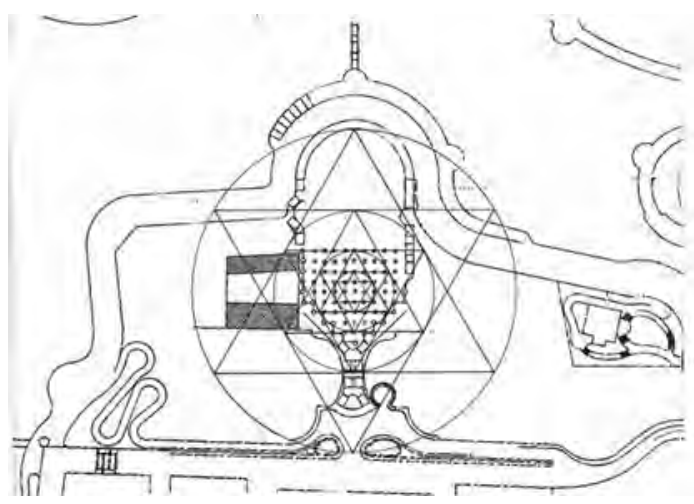

Fig. 3. The four hexagrams outlined on a copy of the plan that Gaudí presented in 1905.
${ }^{8}$ Desiderius LeNZ, The Aesthetic of Beuron and other Writings, London, Francis Boutle, 2002. 
9 For a more accurate explanation of this geometric process, see: C. Rius, Antoni Gaudí..., p. 126-128.
As can be seen, the first two hexagrams coincide with points and lines that exist in the work created by Gaudí, something that does not happen with the third hexagram. With the fourth hexagram an interesting thing occurs: its lower and upper points match with the main entrance to the park and the upper part of the wall of the Nature Square, respectively. Thus, on the plan of Park Güell, we have managed to draw an elaborated figure of the aesthetic geometry by Peter Lenz, which in part coincides with elements of the work made by Gaudí. But now it is not clear how we should continue. And what I propose is to resort to a geometric process that I have reconstructed while studying another work by this architect, Casa Bellesguard, and that can be summarized as follows: ${ }^{9}$

1. A sequence of concentric squares, one located inversely in relation to the previous one, which represents a movement of contraction.

2. A series of expansive hexagrams, all placed in the same position, which reproduces a movement of expansion.

3. A series of concentric hexagrams, one inverted with respect to the previous one, which represents a second contractive action.

4. And the inference of a regular star with five points, following the relations of the golden section or the so-called divine proportion, which, as we will see later, denotes a second expansive movement.

One can realize that fig. 3 presented above corresponds to the second section of this geometric process. And now, from the larger circle of this figure, we can draw a series of concentric squares, one inverted in relation to the previous one, which will be equivalent to the first section of the same process:

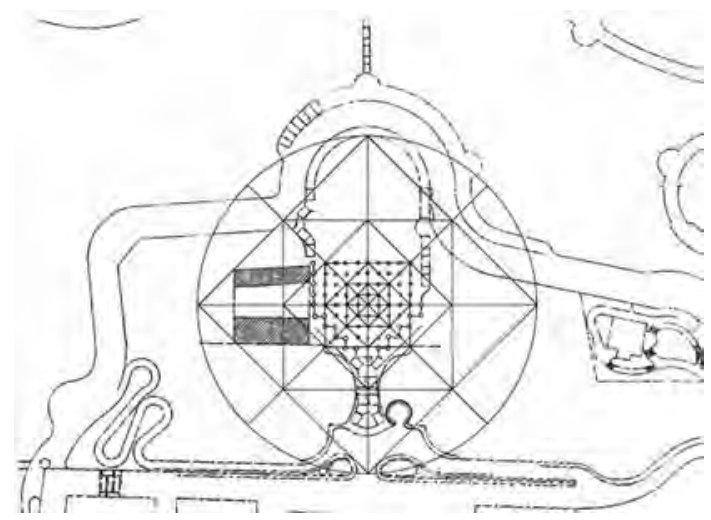

Fig. 4. The concentric squares of the first section of the geometric process, applied at Park Güell. 
As you can see, the lines of the first three squares do not seem to pass through places in the park where there are significant elements. In contrast, the last five squares have sides that coincide with horizontal, vertical and diagonal lines that are formed by columns of the Hypostyle Room. Even more: the sixth square drawn matches with the central square of the Doric Temple that frames the figure of the key of God. However, if we now try to apply the third section of this process, we will realize that the lines drawn do not harmonize with lines suggested by the artistic work existing there, especially as regards the wide space between the Hypostyle Room and the perimeter of the larger circle; and even less so if we try with the fourth section.

Having arrived here, it seems we are at an impasse. And to come out of it, I propose to go further into the set at the end of the sloping portico, trying to infer something more of its content.

\section{The ideological meaning of the set}

Among the influences welcomed by Gaudí, three are often mentioned. The first one came from the teachings he received from different intellectuals, such as the brothers Manuel and Pau Milà i Fontanals, which introduced him to the ideas of German Romanticism and classicism. ${ }^{10}$ The second was the advice given by the bishop Josep Torras i Bages, which contributed to his joining the Artistic Circle of Saint Luke, a grouping of Catholic artists created following the example of other similar groups that emerged in the $19^{\text {th }}$ century, such as the Lukasbrüder (the Brotherhood of Saint Luke). ${ }^{11}$ And the third one was the friendship with the bishop Joan Baptista Grau i Vallespinós, who is said to have introduced him to the work of Prosper Guéranger (first abbot of the monastery of Solesmes, France), who had promoted a renewal of the Gregorian chant, and written the book L'Année liturgique (The Liturgical Year), which Gaudí read assiduously. ${ }^{12}$

However, it was just advancing this last line of research that, on my work on Casa Bellesguard, I discovered the influence of the aesthetic geometry of Peter Lenz on Gaudí. Firstly, because it is well known that the Beuron School of Art was created with the purpose of applying the mathematical relations of the Gregorian chant of Solesmes to plastic arts. ${ }^{13}$ Secondly, since the Beuron School was also directed in the likeness of the Lukasbrüder. ${ }^{14}$ Moreover, some artists related with the Lukasbrüder did some works using a kind of mystical geometry similar to the one that Peter Lenz would develop later. ${ }^{15}$ All these groups of artists that emerged in the
10 Joan Matamala, Antoni Gaudí. Mi itinerario con el arquitecto, Barcelona, Claret, 1999, p. 29-30; Jordi ELIAS, Gaudí. Assaig biogràfic, BarceIona, Circo, 1961, p. 231.

11 Enric JARDí, Història del Cercle Artístic de Sant Lluc, Barcelona, Destino, 1976, p. 23-25.

12 Gijs van Hensbergen, Antoni Gaudí, Barcelona, Plaza y Janés, 2001, p. 134.

13 Martha Dreesbach, "Pater Desiderius Lenz OSB, Theorie und Werk", Studien und Mitteilungen zur Geschichte des Benedicktiner-Ordens, Munich, Bayerische Benediktinerakademie, 1957, p. 5-183: 6-7.

14 Hubert Krins, "Introduction", D. LENZ, The aesthetic..., p. 6-7.

15 C. Rius, Antoni Gaudí..., p. 112-129. 
16 This beginning with the name "Luke", which comes from "lux", meaning "light", so that as the first name of the saint that wrote one of the four Gospels suggests the idea: "the one who came to illuminate the world". See: Santiago de la VorÁGINE, La leyenda dorada, Madrid, Alianza, vol. 2, 1982 (circa 1282), p. 668.

17 J. C. DAZA, Diccionario..., p. 139, and 284-85. $19^{\text {th }}$ century Europe were formed in the image of the medieval guilds of painters that had adopted the name of their patron saint, Luke. And when reading the writings of him, one can identify two main traits: the descriptive manner in which they narrate the major events of Jesus' life; and the important presence of light. ${ }^{16}$ Both traits are particularly well exemplified in the passage from Lk 3:16, repeated in Acts 1:5, which reproduces the following words pronounced by John the Baptist: "I baptize you with water. But one who is more powerful than I will come, the straps of whose sandals I am not worthy to untie. He will baptize you with the Holy Spirit and with fire".

All things considered, we can now say that the set at the end of the sloping portico presumably symbolizes a lodge that wanted to promote a type of society with values such as those of the first Christian communities. This society, however, should be fostered through an art like that created by the brotherhoods that had emerged at the end of the Middle Ages and flourished during the $19^{\text {th }}$ century. And this art should be made with a mystical geometry that interrelated proportion and variation, and which through light expressed the original spirit of Christianity. Besides, for this group, the writings of Luke the Evangelist were important, such as the passage from Lk 3:16 or Acts 1:5.

But this is not all: as I have said, the two pillars of the set represent the entrance to a masonic temple located from west to east. And in the symbolism of this society, the east means the direction from which light comes, both the light of the sun and the spiritual light that should guide the works of the apprentice. ${ }^{17}$ In addition, any person who visits the Park Güell at different times of the year, will perceive the importance of the relation between sunlight and the diverse parts of this work, especially when the sun rises close to east and moves very low the whole day, i.e., around the winter solstice. By the way, according to the Liturgical Year, this is the time when Christians celebrate the birth of Jesus. To sum up, it seems that Gaudi built the set also to suggest visiting this site of Park Güell just in the dates mentioned above, for witnessing something. This is what I did in December 2015 - January 2016. And now I will explain to you what I could see.

\section{The sunlight at the beginning of winter}

Every year, around 21 December, the winter solstice takes place, which involves a change in the length of the day and night. In the case of BarceIona city, located in the northern hemisphere, this is the day the sun rises 
and sets closest to the south-east direction, taking the lowest path above the horizon, and resulting in the shortest day of the year. From that day on, the sun will rise further to the north-east, take a longer path in the sky, and set further to the north-west, resulting in longer days.

All this means that if you visit Park Güell in the daybreak of December 21 , you will see the sun rising over the sea at 8.14 am. ${ }^{18}$ From then on, the red light illuminates the Nature Square, the set being one of the first places radiated. And if you then visit the Hypostyle Hall, you will see the following: first the sunrays enter diagonally from east to west, penetrating the temple until touching the background wall; and when the sun moves south and situates in a straight line with the central row, the shadows of the columns align with the same pillars, the light falling on extensive areas of the floor, reflecting to the ceiling, and filling the whole temple with an intense luminosity. This is a unique moment when sunlight emphasizes architectural symmetry, an excellent example of artistic and natural beauty. And considering the dates when this happens, these phenomena may mean the following: the sun represents the coming of Jesus, and the light produced inside the temple signifies the Spirit he brought, the one revealed during his baptism; both events expressed in the Gospel of Luke.

Even so, there are more questions: one of them is why Gaudí built the Doric Temple in a way that in the moment of its maximum illumination, in the centre, the light only arrives until column seven, while leaving dark number eight, which still belongs to the extreme area of the key of God. In addition, in that moment the sun medallions shine exceptionally, reappearing now the question about the meaning of their distribution; a question on which I would like now to say some words.

Earlier I have proposed a meaning for these medallions: alluding to a figure that had already been worked with by Pythagoreans, alchemical thinking and Peter Lenz, considering it the starting point of a geometrical process until achieving the divine proportion, which would produce an explosion of light. Yet now that we have found that these sun medallions are also related to the seasons, let's see if we can understand something more about them. In this sense, it may be useful for us to resume the situation of these four medallions in relation to the pillar that I have previously called the sixth column, but now considering it not only the centre of the key of God, but also of the four points of the compass; a representation alluded to by the four-armed cross that crowns the pinnacle of the Reception Pavilion. Here I present an image of this representation:
18 In Catalonia, in winter, the official time is one hour ahead of solar time. So that day the sun rises at 7.14 am of the solar time. 


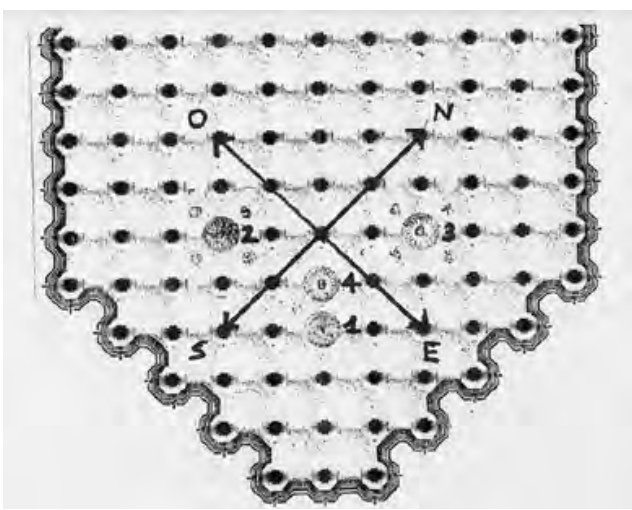

Fig. 5. The four sun medallions in relation to the points of the compass.

In this image, one can observe that the medallions I have enumerated 1 and 4 are located $45^{\circ}$ from the straight lines that indicate the south and the east directions. Medallion 2 is situated in the same angle in relation to the straight lines that signal the south and the west; and the same happens with number 3 , but referring to the lines that indicate north and east directions. With this, we can realize that medallions 1 and 4 are located on the same straight line where the real sun situates when in the day of the winter solstice it produces the complete symmetry in the Doric Temple. So we can suppose that one of these medallions refers to this real sun; and from there, to infer the meaning of the others.

Thus, based on what happens in the solstices and equinoxes, as well as the knowledge of the points where, seen from Park Güell, the sun rises and sets during the whole year, we can now realize that three sun medallions can be considered representations of the places where this star rises and sets in the two solstices, meaning the following:

- Medallion 1: the place where the sun emerges on the winter solstice, meaning autumn.

- Medallion 2: the point in which this star sets on the same day, representing winter.

- Medallion 3: the place where the sun rises on the summer solstice, alluding to spring.

And now we just need to know why medallion 4 is $45^{\circ}$ in relation to south and east, instead of being $45^{\circ}$ relative to north and west. In this sense, I would like to introduce a hypothesis: this medallion 4 might represent the star of the summer solstice day, but before it reaches its destination. It is not easy now to understand why Gaudí chose this place for medal- 
lion 4; and to grasp it, presumably we will have to wait and see what happens in Park Güell on the summer solstice day. In the meantime, what we can do is to keep watching if, around the winter solstice days, other interesting things happen there.

\section{The sphere and the light of the soul}

The symmetry with sunlight that I have explained only lasts for a few seconds, as the sun continues its path to the south, causing the shadows of the columns to move out of their alignment and stretch on the right side of the temple. Well, just after this alteration, the following occurs: in the nave of the temple located more in the north-east part, the entering sunlight illuminates the stone wall of the background with an exceptional brightness. And if you are near this wall, and from there look in the opposite direction, you will see the top of the Porter's Lodge and how the sun is situating in a vertical line in relation to its central axis, where there is the form of a mushroom that crowns the roof and a round window that has a white Greek cross made of trencadís. So, after all that has been seen that day, one might wonder if the luminous phenomena will continue inside this building.

When visiting the interior of this pavilion, one finds: on the ground floor, the dining room, the living room and the kitchen; on the first floor, the bedrooms; and on the second floor, the attics. The four bedrooms are distributed on both sides of a long corridor that crosses through the middle of the entire width of the house. Parallel to this corridor, there is a flight of stairs that goes up to the garret. And this attic has: a vaulting ceiling, a

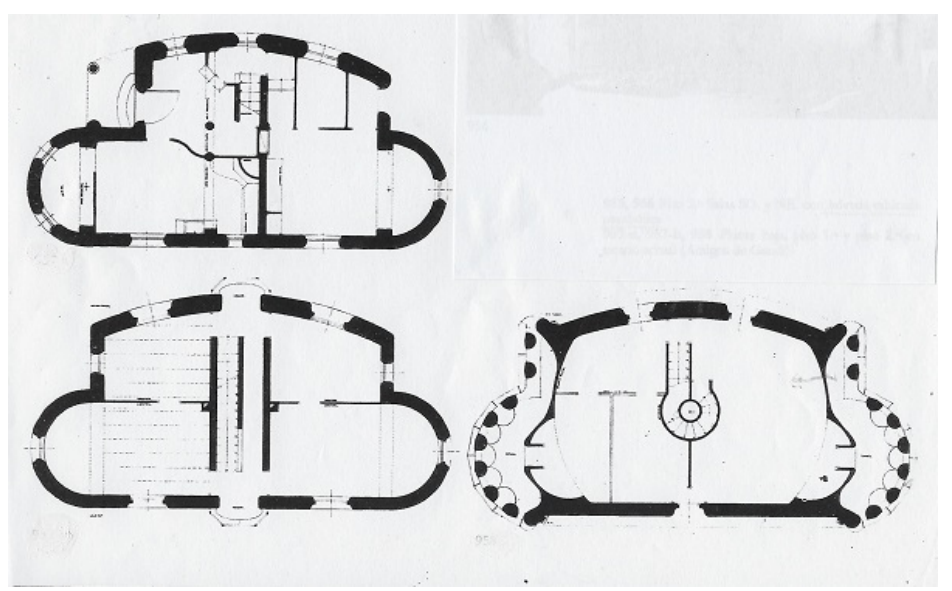

Fig. 6. Plan of the three floors of the Porter's Lodge at Park Güell. 
partition wall oriented in the same direction as the staircase, and at the midpoint of it, a cylindrical shape that constitutes the exterior wall of a spiral stairwell.

In this image, you can see how in this pavilion the spaces and the openings are distributed following a bilateral symmetry conditioned by a straight line that crosses the width of the building, which is clearly perceived on the two upper floors. On the first floor, this central line is justified since the corridor distributes the bedrooms in a balanced way. But this is not the case with the attic, where the partition wall fragments and hampers. This is clear when one sees that this wall divides into two parts the round window seen from the temple, as well as another equal window situated in the south-east facade. And that applies even more when one contemplates how the sun wanders in front of the south-eastern facade and its rays enter through the openings of the round window, reflecting half the cross in one room and the other half in the other room, breaking not only radial, but also bilateral symmetry. Then, one wonders if Gaudí placed this wall in this way suggesting that the visitor finds out how the broken harmony could be restored. In this sense, I now propose to study the shape of the Greek cross reflected in a distorted way on the walls.

When, early in the morning of those days, the low sun moves from east to south, the sunrays that enter through the Greek cross window of the south-eastern facade reflect fragmented from west to north on the interior walls of the attic. However, there are also some circumstances when it happens as if the shape of the Greek cross were reflected entirely in a single space. Thus, if you go to the frame of the door that is in the south-eastern front, situate leaning your back against the square window that is in this wall, and from this position observe the displacement of the reflections mentioned above, you will verify that there is a moment when one can also see the two reflected halves of the Greek cross coupled on the surface of the two halves of the cylinder. Therefore, also inside the building, even for a few seconds, it is possible to contemplate a beautiful image of the whole Greek cross with all its radial symmetry restored; an image that precisely at these dates occurs at the half height of the cylindrical form. Moreover, on the days that go from the end of December to the beginning of January, at the same time that this symmetrical reflex happens, another similar one - but weaker - occurs on the opposite side of the cylinder: one produced from the light that enters through the Greek cross window situated in the north-western front of this building, and which comes precisely from the exceptional reflection that in that moment is happening on the north-eastern nave of the Doric Temple. So we have discovered that on the same days when the special lighting phenomenon occurs in the Doric Temple, there are 
indeed other remarkable ones in the attic of the Porter's Lodge, which happen only a quarter of an hour later.

But with this double reflection on the central cylinder, a second straight line is also made clear: one that passes through the middle of the cylinder, and which is perpendicular to the one marked by the partition wall. These two perpendicular lines reveal a radial symmetry prevailing on the horizontal section of this attic; a symmetry that happens inside a large circle in whose centre there is the cylinder. And this figure is important since it contains the three basic forms that above we have seen shape the key of God, and from which Peter Lenz reconstructed the other forms of the divine language. So, now that we have rediscovered this figure here, in the Porter's Lodge, we can try to develop the whole geometric process that we have left only half done in the Doric Temple.

In order to apply this geometric process to this building, we will begin by taking the large circle of the key of God rediscovered there. Within it, we will draw the first two sections that we have already traced at the centre of the temple. And then we will outline the hexagrams of the third section, until achieving the following result:

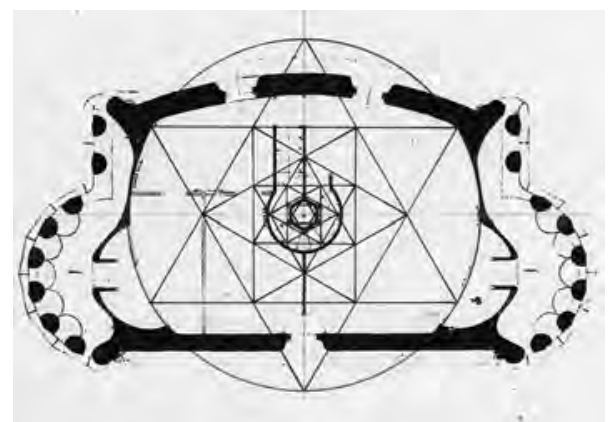

Fig. 7. The third section of the geometric process, in the plan of the garret of the Porter's Lodge.

Regarding this last image, I would like to remark that if you draw a circumference that touches the sides of the core of the larger hexagram, you will see that it coincides with the circumference that can be produced by coupling in the centre the two semicircles that form the two side balconies. And something similar happens with the circumference that embraces the points of the third hexagram outlined, in relation to the circumference that can be created by assembling the two semicircles that form the side apses.

And finally, let's see if we can infer the fourth section of the geometric process. To do this, we will start from the core of the fifth concentric hexagram, the one inserted inside the circle that marks the perimeter of the 
19 D. LENZ, The Aesthetic..., p. 64-65.

${ }^{20}$ Acts 1:5; 2:2. central axis of the spiral staircase, and which has the shape of a regular hexagon. But this polygon can also be the shape of an icosahedron seen from a specific perspective. And observed from another viewpoint, an icosahedron takes the form of a regular pentagon. Therefore, inside the circumference of the spiral staircase, we could draw a pentagon instead of the hexagon, and consider it another perspective of an icosahedron. Now, from that pentagon, we outline a regular pentagram, a five-pointed star that has the pentagon as its core. Next, we draw a second star pentagon that has the first one in its core, and that is located inversely. And if you draw a circumference that embraces the five points of this second star, you will see that it coincides with the dimensions of the circumference we have created when coupling the two semicircles of the two side balconies.

When relating these forms, we can realize that they correspond to the proportions that exist when locating an icosahedron in the centre of a dodecahedron, in the relation called "conjugate or dual polyhedron", which fulfils the divine proportion in three dimensions. And this figure is especially interesting for us because it is similar to the one that Peter Lenz called the sphere of the five regular solids, and characterized as luminous. ${ }^{19}$ So I think it is plausible to suggest that this figure we have inferred in the Porter's Lodge alludes to the sphere of Peter Lenz, so that the double reflex that we have verified that occurs in this space becomes an expression of the radial luminosity that emerges from the centre of this sphere. And this turns the attics of the Porter's Lodge into the room that Gaudi left to us in order to learn how to move from sunlight to the light of the soul.

Having said that, now we can try to understand what we have just discovered, from the viewpoint of some of the cultural traditions alluded to in Park Güell. Thus, from the perspective of alchemical thought, the luminous experience generated by the perception of the sphere of the five regular solids, signifies the moment when the philosopher's stone is discovered. And from the viewpoint of biblical history, the finding of this sphere in the Porter's Lodge signifies the event that John the Baptist announced, i.e., the baptism of the disciples with the Holy Spirit, which, according to Luke: happened inside a house in Jerusalem; it was expressed through light, and provided the disciples with a knowledge that allowed them to spread the Christian message. ${ }^{20}$ But what these traditions indicate to us is that the most important thing of this sphere is the light that it generates and its effects, so that we can think that if in the urbanization of Park Güell this sphere had to nourish a feeling of community, it should also be located in the centre of the Doric Temple... 


\section{Second applications of aesthetic geometry}

When returning to the centre of the Hypostyle Room and measuring the space between two pillars, you will verify that the distance between two adjoining columns is exactly $4 \mathrm{~m} .{ }^{21}$ This means that the distance between three adjoining columns is $8 \mathrm{~m}$, and this measure is very similar to the diameter of the large circumference of the Porter's Lodge in whose interior we have inferred the whole geometric process. So, if we take the sixth column of the Doric Temple as the centre of a circle that has a diameter of $8 \mathrm{~m}$, the same geometric process inferred in the Porter's Lodge can be applied to the centre of the Hypostyle Hall. Now, this circle can be doubled outward, so that it is $16 \mathrm{~m}$ in diameter. We can frame this second circle with a square whose sides also measure $16 \mathrm{~m}$, corresponding to the distance between five columns of the Doric Temple. This larger square is the same quadrilateral that above we have seen frames the four sun medallions that form the image of this temple. And this quadrilateral also coincides with the sixth concentric square of the first section of the geometric process applied to the centre of Park Güell (fig. 4). In this way, we have managed to join the geometric process completed in the attic of Porter's Lodge, with the process that we had started in the centre of Park Güell. And now the first one can be considered a useful model for finishing, on a larger scale, the second one, drawing the third and the fourth sections of that process, until obtaining the following figure:

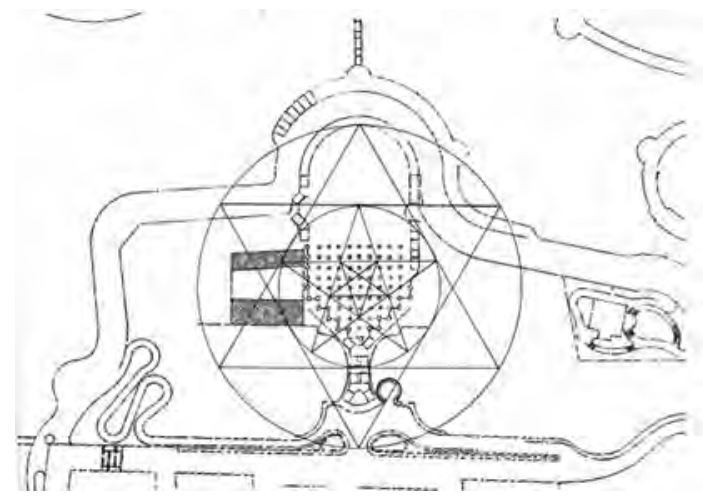

Fig. 8. The pentagonal shape and the two pentagrams.

Now we can glimpse the responses to some of the questions I raised above: if, as mentioned before, the solar medallions in the Doric Temple signify the light arisen in any genuinely creative act, we can now understand this light as the spiritual one generated by the sphere that contains
${ }^{21}$ All the dimensions presented below have been taken from plans, and also measured in situ. 
the divine proportion; and if we have seen that, when the symmetry with sunlight that occurs around the winter solstice day, this light only arrives until column number seven of the centre, we can now understand that from that point on it will have to be enlightened through the spiritual light we have learned to generate with aesthetic geometry. However, there are some aspects that remain unclear, such as:

1. What area of the Doric Temple should exactly be illuminated by the light of the sphere.

2. And why some of the lines drawn with the application of the geometric process still do not seem to coincide with anything conceived by the author of this work, especially with respect to the upper part of Nature Square.

Briefly: we will have to continue searching. But now I do not think it makes sense to keep on exploring the central area of the park, but outside it; and it is not clear how to do it, given the difficulties of applying aesthetic geometry in the sinuous shapes that surround that centre. Even so, two ideas spring to mind: as at other times, from a specific point in the centre, drawing a straight line that leads us to another place, but located outside; and to accomplish this task, we may make use of the spiritual light we have learned to generate. In this sense, when examining the centre of Park Güell, we can find several signals that point outside the large circle. Among these elements there are some oriented toward the forest that is behind Casa Trias. And from all these lines, there is one that departs from the space where we have discovered the philosopher's stone, i.e., the Porter's Lodge. Thus, if you climb the spiral stair that goes inside the cylinder of the attics, you will see that it goes until a circular terrace, but through a door oriented towards the forest that is at the highest part of the park. It seems nothing visible justifies such direction; but there is another possibility: this opening may indicate something to look for...

\section{The transmuted rock}

After having drawn a straight line from the door of the terrace of Porter's Lodge towards the forest situated at the highest part of the park, and having searched intensively among bushes and stones, I have found, in a rocky clearing that crowns the hill, a stone with a green painted image consisting of a Greek cross surrounded by other signs. And to argue that this is the object indicated from the centre of Park Güell, I can say the following. 
Firstly, the Greek cross is a remarkable symbol of the aesthetic geometry of Peter Lenz, which Gaudí also placed in key points of his works such

22 Lk 24:50-53; and Acts 1:1-12. as Casa Bellesguard and Park Güell. In addition, the green colour is an important symbolic element in the work of Lenz, and it is also present in several elements of Park Güell. Secondly, this rock with the image of a cross can also be interpreted by means of the cultural traditions we have found expressed in this work: from the point of view of alchemical thought, the green graffiti on the rock can be understood as a first expression of turning impure metals to pure metals, which allows us to call this object the transmuted rock; and from the viewpoint of biblical tradition, this rock with the image of a cross located at the highest part of the park, can mean the ascension of Jesus. ${ }^{22}$ And thirdly, when empirically studying this rock with the image painted, I have discovered the following aspects. The stone is located at 212.50 metres above sea level. It is the surface of a buried, steady rock, which can hardly be moved. The image that has been painted on it consists of a cross patty, around whose arms there are other signs more difficult to decipher.

Moreover, it turns out that: the four arms of the cross are oriented to the four cardinal points; under the south arm, there is a serpentine form very similar to the shape of the road that goes by the side of Casa Trias; and if you take a plan, and from the southern arm of the cross you trace a straight line, you will see that this line passes through the sinuous path that I have just referred to; even more, if you continue to draw this line southwards, you will observe that it goes to the centre of the park, and that it passes through column number ten of the central row of the Doric Temple.

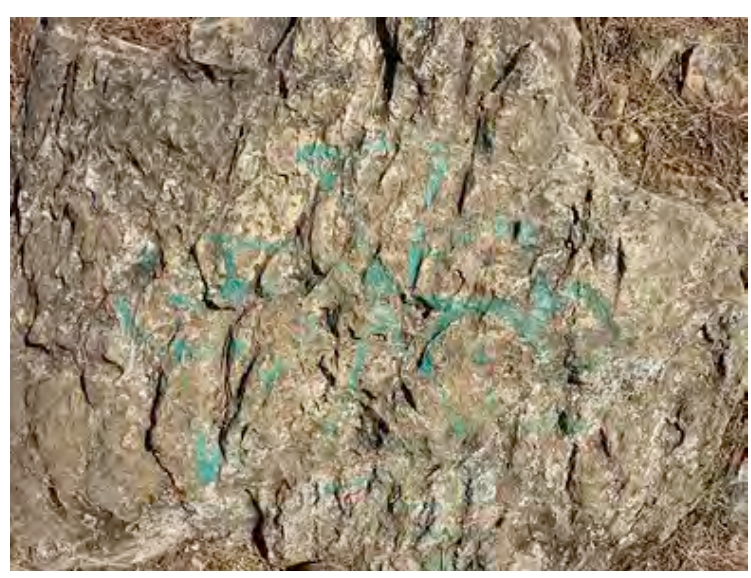

Fig. 9. Image of the transmuted rock.

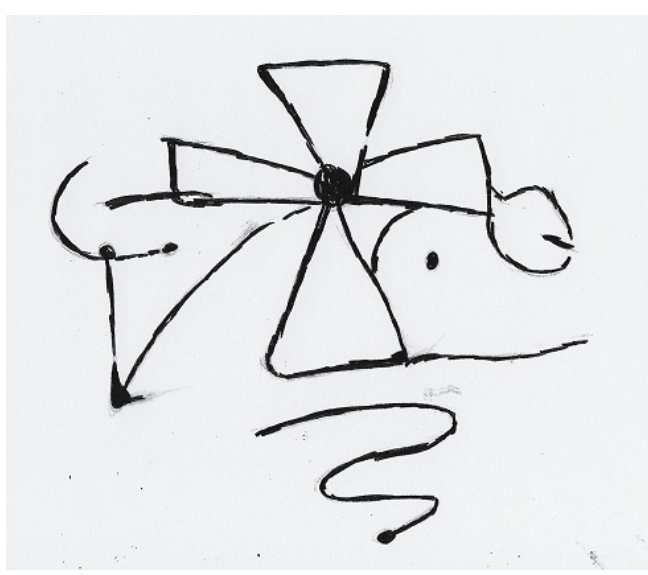

Fig. 10. Drawing of the main lines identified in the image painted on the rock of the mountain. 
23 Oriol Bohigas, "El Hospital de San Pablo", Cuadernos de Arquitectura, n' 52-53, 1963, p. 47-60; and Sergi Alcalde Vilà (et. al.), Lluís Domènech i Montaner (18491923). Obra arquitectònica raonada, vol. 1, Canet de Mar, Centre d'Estudis Lluís Domènech i Montaner, Els 2 Pins, 2016, p. 571-641.

24 Joan BASSEgoda I NoneLL, "L'arquitecte Bernardí Martorell i Puig (1877-1937)", Butlletíde la Reial Acadèmia Catalana de Belles Arts de Sant Jordi, vol. 17, 2003, p. 35-55; and Antoni Albacete I GASCón, i Margarida GüELL i BARó, EI reial monestir de Santa Maria de Valldonzella (1147-1922), Barcelona, Abadia de Montserrat, 2013. On how aesthetic geometry is present in this building, I gave a presentation in the III coupDefouet International Congress on Art Nouveau, entitled "Aesthetic Geometry and Light in the Church of Valldonzella Monastery", and which soon will be published in the proceedings.

${ }^{25}$ La Casa de Maternitat $i$ Expòsits. Les Corts, (VARIous AUTHORS), Barcelona, Ajuntament de Barcelona, Diputació de Barcelona, Xarxa de Municipis, 2004, especially, p. 218250.

26 Juan José LAHUERTA, Gaudíielseu temps, Barcelona, Barcanova, 1990, p. 101-141; J. BASSEGODA I NonelL, El gran Gaudí..., p. 255-279.

27 J. F. RÀFols, Gaudí (1852-1926), Barcelona, Aedos, 1960, p. 18-19; and J.
With this in mind, we can say that this image of the transmuted rock is related to the work done in the centre of Park Güell, and even that it was probably painted by Antoni Gaudí himself. In this light, what we can now say is that column number ten of the central row of Doric Temple is one of those that only will be able to be illuminated by means of the "light of the soul"; and that this tenth column is situated just at the point where the dynamics of the undulating bench end, and the static quality of the stone wall of the Nature Square begins. So we can assume that if we managed to find out the meaning of the transmuted rock, this may help us to solve the remaining open issues. In this sense, what I propose is the following: taking a map of the Barcelona city; pointing out the place where the transmuted rock of Park Güell is located; from the centre of its cross, drawing unlimited lines in the east, the west, the south and the north directions, and examine if on these lines there is any construction done through aesthetic geometry by Peter Lenz.

\section{The symbolic route}

Having found different constructions with these features, I have studied them in depth one by one. Here, however, because of space limitations, I will confine myself to listing some of them, and giving references I have used and of some study I have already presented.

1. The east arm of the cross points to the Hospital de la Santa Creu i Sant Pau. Lluís Domènech i Montaner directed the construction of this work from 1901 to $1913 .^{23}$

2. The west arm of the cross signals the Monestir de Santa Maria de Valldonzella. This new monastery for the community of Cistercian nuns was constructed between 1912 and 1919 by the architect Bernardí Martorell i Puig. ${ }^{24}$

3. In fig. 10, one can see a line that starts from the centre of the cross and goes diagonally in relation to the right angle formed by the west and the south arms. And this line points to Casa de la Maternitat $i$ Expòsits. The architect who made the project and from 1890 to 1898 directed the construction of the first pavilions, was Camil Oliveras Gensana. ${ }^{25}$

4. In the image painted on the transmuted rock, from the point that represents the Casa de la Maternitat, a short line leaves to the north. The point where this line goes corresponds to the Pavilions of Finca Güell, which Gaudí built for Eusebi Güell from 1884 to $1887 .{ }^{26}$

5. On the right hand of the image, under the east arm of the cross, there is a horizontal line. The point where this line begins corresponds to the 
Water Deposit in the Parc de la Ciutadella, constructed from 1874 to 1880 by Josep Fonteserè i Mestre. Antoni Gaudí made the structural calculations of the whole reservoir and its support elements. ${ }^{27}$

6. The south arm of the cross, going beyond the tenth column of the Doric Temple, points out the Hospital Clínic i la Facultat de Medicina. The architect who directed the works of this construction from 1895 to 1906, was Josep Domènech i Estepà. ${ }^{28}$

7. And the north arm of the cross indicates the land of what once was the Granja Martí-Codolar, about which now I would like to add a few more words.

The Granja Marti-Codolar is a farmhouse with a long history. But of all its owners, the ones that interest us the most are the siblings Lluís and Joaquima Martí i Gelabert, who in 1856 received as an inheritance what was known as the Granja Vella and the Granja Nova. Lluís Martí i Gelabert - who later changed his name into Lluís Martí-Codolar - employed the master builder Jaume Brossa i Mascaró to renovate his farm in 1890. And according to what has remained, there are signs that indicate that in this remodelling some elements related to aesthetic geometry were introduced, e.g., in the symbols present on the main facade referring to the myth of Heracles; in the new distribution of rooms on the second floor, and in the proportions of the clock tower. ${ }^{29}$

However, on the plots that once belonged to the Granja Marti-Codolar, there are more elements connected with aesthetic geometry, which I would like to explain below. It turns out that a year after having started the reforms in the Granja Vella, the business of Lluís Martí-Codolar began to go badly. Consequently, in 1893, he had to sell the Granja Vella to his sonin-law; and in 1894, his sister also had to sell the house she had built on the land situated just above the old farm. Later, that land had different owners, until the year 1908 when it was acquired by the community of nuns of St. Francis of Paola, who in the same year began to build a monastery that later was called the Monestir de Jesús Maria. About this building, the truth is that there is little information, so that the only thing I have got to know is that it was erected from 1908 to 1914, just when Antoni Gaudí stopped working on Park Güell. ${ }^{30}$ In this case, it is a building that has undergone minor renovations, and that still serves as an enclosed monastery, but whose church can be visited. This church has a very simple form: a single nave, which measures $30 \mathrm{~m}$ long by $9 \mathrm{~m}$ wide, and a crossing, that measures $9 \mathrm{~m}$ by $9 \mathrm{~m}$. And in this building aesthetic geometry is present in different ways, of which I would like to just briefly mention two:
BASSEgoda i NonelL, El gran Gaudí..., p. 110-113.

28 Joan BASSEGODA I NONELL, "L'obra de Josep Domènech i Estepà, arquitecte de la Facultat de Medicina i Hospital Clínic de Barcelona", Gimbernat, 45, 2006, p. 17-26; and Sergio Fuentes Milà, Josep Domènech i Estepà. Últim arquitecte municipal de Sant Andreu de Palomar (1883-1897), Sant Andreu de Palomar, Centre $\mathrm{d}^{\prime}$ Estudis Ignasi Iglésias, Llibre de Finestrelles, n 9, 2016.

29 On this remodelling, see: Ramon AlBERDI, and Rafael CASASnovas, Els jardins de Martí-Codolar. La Granja VeIla, Barcelona, 1999, p. 74-82; and Ramon ALBERDI, and Rafael CAsasnovas, Martí-Codolar. Una obra social de la burguesia, Barcelona, Obra Salesiana Martí-Codolar, 2001, p. 194199.

${ }^{30}$ In the Archive of the Barcelona City Council there is no plans of this building, and nowhere appears the name of the architect that constructed it. The only information on it I have got is in the Property Registry of Barcelona number 11, documentation of building number 1.082, Items 12-17. 
${ }^{31}$ On the walls of the crossing, a biblical sentence pronounced by the Israeli Gideon is reproduced (Jgs 6:15); a sentence that is very similar to the one pronounced by Virgin Mary in the Annunciation ( $L k$ 1:34).

$321 \mathrm{Kin}$ 6:2-22; and Ezk 45:1-5.
1. The ceiling of the crossing is decorated with three large concentric squares, one situated inversely in relation to the previous one: figures of the geometric process, which here symbolize Gideon's dry fleece raised to the heavens, as well as the Virgin Mary's Assumption and Jesus' ascension. ${ }^{31}$

2. And the dimensions of this church correspond to the measures of the Temple of Solomon as they are explained in the Bible, ${ }^{32}$ and also as they can be conceived through aesthetic geometry. In this respect, one needs to bear in mind that just in 1913, a disciple of Peter Lenz called Odilo Wolff published a book entitled Der Tempel von Jerusalem. Eine kunsthistorische Studie über seine Masse und Proportionen, where he tried to show how the proportions of aesthetic geometry could explain the different dwellings that Jewish people had built to house the Ark of the Covenant: the tabernacle, Solomon's Temple, the reconstruction by Zerubbabel, and the extension by King Herod.

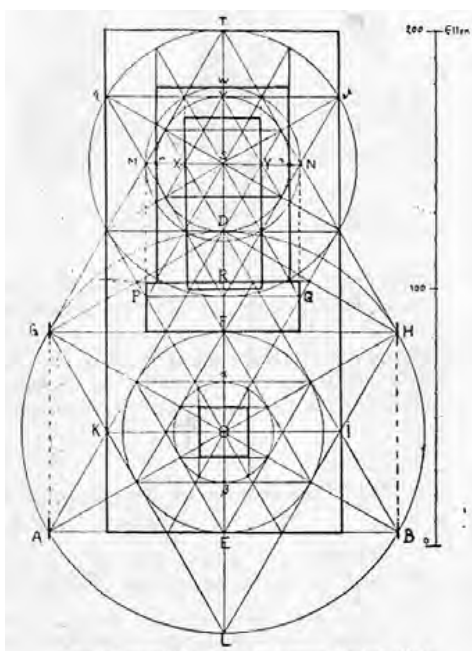

Fig. 11. Drawing of the Temple of Solomon, with the sanctuary, the inner court, and the altar of burnt offering, interpreted through aesthetic geometry. Odilo Wolff, 1913, p. 41.
In short, we can say that the church of the Monestir de Jesús Maria was built with the same proportions as Solomon's Temple, and conceived through aesthetic geometry, so that the crossing represents the Holy of Holies of this temple, where the tablets of the Ten Commandments that God had revealed to Moses were held, and also the space where a second revelation took place, the one coming of the Holy Spirit, which allowed Virgin Mary to give birth to the Son of God. And in the same space, this mystical geometry represents a movement in the opposite direction: the Ascension of Jesus and Mary's Assumption.

In my view, this is a crucial finding not only to understand the meaning of this monastery, but also in relation to the other places of the symbolic 
route, since in all of them there is a construction with a central space that measures $9 \mathrm{~m}$ by $9 \mathrm{~m}$, where the same geometrical process can be inferred and with the same supposed meaning. In this way, we have found what is common in all the places indicated on the transmuted rock. And now, with all these data, we can return to Park Güell and try to solve the outstanding issues.

\section{The imaginary Temple in the centre of the park}

To return from the Granja Martí-Codolar to Park Güell, we can take a straight line that starts off from the eastern side of the Monestir de Jesús Maria, passes through the main facade of the Granja Vella, and going southwards through several neighbourhoods of Barcelona, it arrives at Park Güell, just at the centre of the semi-circumference formed by the stone wall that closes the north-west part of Nature Square.

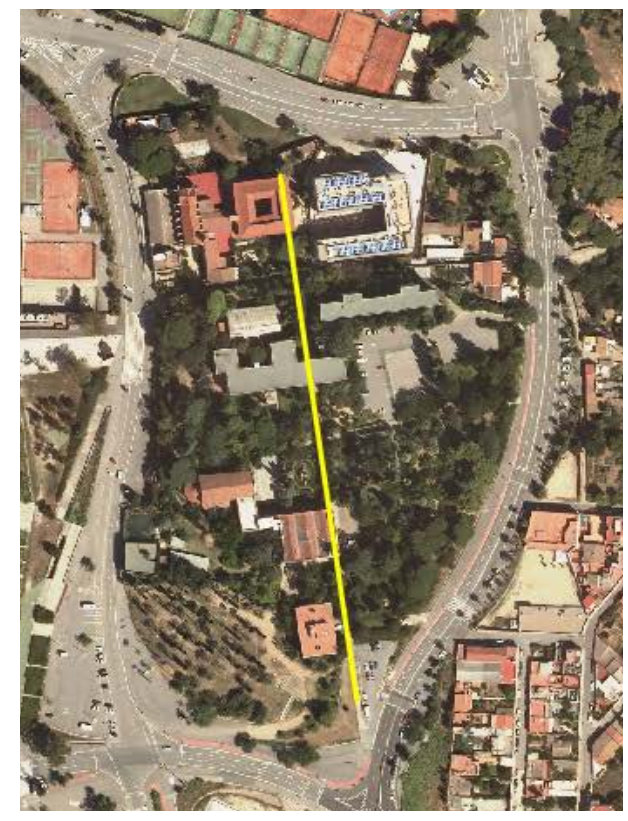

Fig. 12. View of the Monestir de Jesús Maria, above, and the Granja Vella Marti-Codolar, below, connected by the straight line mentioned.

Now, with what we have learnt on our symbolic route, let's see if also in Park Güell there is such a figure of Solomon's Temple, and if its finding 
allows us to answer the questions we left unresolved. To start this rebuilding, we will consider whether the analysis already done in this area provides us with useful material. In this sense, at the centre of the park, we have located three notable points: in the central row of the Doric Temple, the sixth column - the centre of the entire geometric process - and the tenth column - where we have arrived through the line drawn from the cross of the transmuted rock, and at the top of the Nature Square, the centre of the semi-circumference formed with the stone wall. Well, we can now realize that these three points are on a same straight line. So we can assume that if in Park Güell there is an imaginary Solomon's Temple, this must be extended along this line, and with the same disposition as the elements built by Gaudí, i.e., starting by the side of the entrance to the park, and ending at the top of the square. And to know where exactly the supposed Temple begins and ends, I would like to revisit the part of the park we saw at the beginning of this work: the Laundry Room Portico.

Thus, this arcade starts with a spiral ramp, then comes a straight section located behind the Güell House, and finally there is another straight section perpendicular to the previous one, which ends with the caryatid and the two symmetrical columns next to the Doric Temple. Well, the first straight section is formed by ten sloping pillars, each with a straight column in its outer part. In these straight columns, two types can be differentiated: some that imitate palm trees, and others more elaborated that seem to look like for a model for the architecture. And the criterion of such differentiation may be explained as follows. If we compare the arrangement of these columns of the Laundry Room Portico, with the arrangement of the central longitudinal row of the Doric Temple, we will observe that both have ten columns, and with the same intercolumn, namely, four meters. And now we can reconsider the straight columns of the Laundry Room Portico, to specify the meaning of the apparently equal columns of the central row of the Doric Temple. Thus, of the ten straight columns of the first section of the Laundry Room Portico, those that stand out for having a more elaborated work are columns number one, two, three, six, and nine. And if we relate what appears in these pillars, with the corresponding columns of the central row of the Hypostyle Hall, we can determine the following:

- The straight columns number one, two and three of the arcade, correspond to the first three columns of the central row of the Doric Temple, and indicate the entrance to the inner court of the Temple of Solomon, from the outer court that King Herod built.

- The straight column number six, is in accordance with the sixth co/umn, centre of the key of God and of the geometric process in the mid- 
dle of the park, and is equivalent to the altar of the burnt offering of the Temple of Solomon.

- And column number nine, since the first section of the Laundry Room Portico is slightly oblique in relation to the longitudinal arrangement of the columns of the Doric Temple, it corresponds to the tenth column of the central row of this hall, and indicates the level where the two columns Jachin and Boaz of the Temple of Solomon are.

In this way, we have managed to locate where in Park Güell the sanctuary of the Temple of Solomon is, and it remains to figure out how beyond the stone wall of the Doric Temple the various parts of this sanctuary develop. Thus, its entrance is just behind the stone wall, namely, $2.5 \mathrm{~m}$ away from the tenth column of the central row. From there, the Vestibule begins, which according to the Bible measures $9 \mathrm{~m}$ wide by $4.5 \mathrm{~m}$ long. Then, there is the Holy Place, which measures $18 \mathrm{~m}$ long and is alluded to by the final part of the serpentine bench, which in this area acquires very particular features: softer meanders that accentuate the longitudinal direction, and a trencadís with whiter tones and simple figures that clearly can be related to aesthetic geometry. And now is the time to locate the most important space of the Temple: the so-called Holy of Holies or Inner Room. And the main element that indicates to us where this space is, is just the straight line that comes from the Granja Martí-Codolar, so that the centre of the holiest room is the central point of the semi-circumference formed by the stone wall of Nature Square.

By doing this, we have come to reconstruct the Temple of Solomon that Antoni Gaudí devised at Park Güell. We can say that this representation is an inner image fostered through external elements. But once we have managed to figure this representation, I do not see why we cannot present an external image of it:

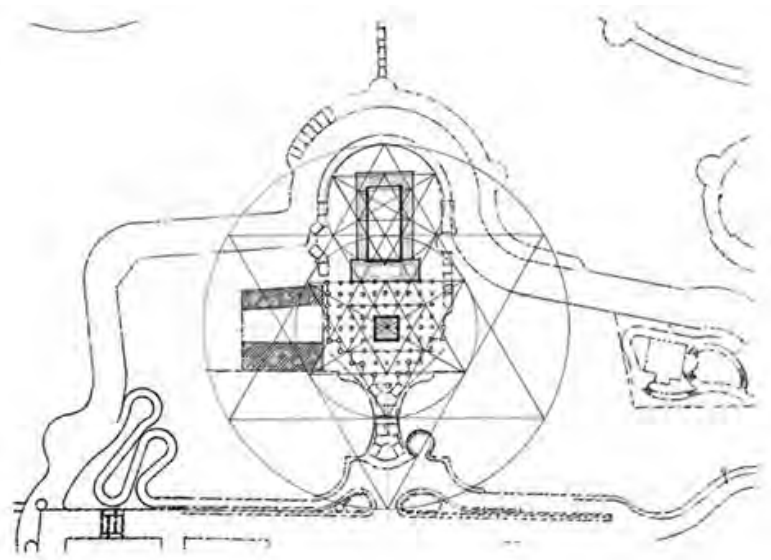

Fig. 13. The Temple of Solomon in the centre of Park Güell, following the aesthetic geometry. 
33 About the Second Temple of Jerusalem conceived through aesthetic geometry, see: Odilo WoLFF, Der Tempel von Jerusalem. Eine kunsthistorische Studie über seine Masse und Proportionen, Vienna, Anton Schroll, image of p. 46.
In this image, you can see the location of the imaginary Temple, in relation to the application of the second section of the geometric process - fig. 3 of this paper - and with Odilo Wolff's reconstruction of the Temple of Solomon by means of aesthetic geometry - fig. 11 of this paper. This approach allows us to understand that the reproduction of the Temple of Solomon thought by Gaudí corresponds to the one of King Herod: the so-called Second Temple of Jerusalem, which existed when Jesus lived. ${ }^{33}$

And now, with this location of the imaginary Temple of Solomon, it is time to come back to the unresolved questions. Thus, it is the location of this Temple that justifies the greater length than width of the Nature Square. With reference to the contrast between the dynamic undulating bench and the static stone wall in Nature Square, I think that Gaudí stressed this opposition in order to foster the search for the meaning that allows one to overcome it; and this meaning consists not only in discovering the reproduction of the Temple of Solomon alluded to by the work of art, but also in experiencing the consequences of such a finding: the opening of a kind of corner in the soul, which, when being cultivated, becomes a source of creativity. And we can also solve another enigma of this work: the meaning of the legends dedicated to the Virgin Mary, which appear on the undulating bench. Now that we have discovered that in Park Güell there is a representation of the Temple of Solomon, a sanctuary with a central space that is precisely dedicated to the laws that God revealed to men and women, including the laws of the Incarnation, we can understand that these legends refer: first, to the Inner Room of the Temple where this double revelation concentrates; and second, to the inner room of the person where that first representation has taken root, giving rise to an interior dialogue.

\section{The sun that never sets}

Nevertheless, there are still two main questions to be solved:

- Why, when on the day of winter solstice the sun situates in a straight line with the central row of the Doric Temple, the sunrays only reach until column number seven.

- And why one of the medallions of the Hypostyle Room, number 4 in fig. 5 , is located in column number five of the central row, and not in column number eight, where it should be to represent the sun that sets on the summer solstice day, and therefore, the beginning of the warmest season. 
As I have suggested above, to answer these questions, one has to visit Park Güell on the days around the summer solstice. This is what I did on 23 June, 2016. And what I could see is the following. As the reader should already know, the day of the summer solstice is the day in which the sun rises more in the north-east, and sets more in the north-west, taking a long path and resulting in the longest day of the year. This implies that when the sun situates just in a straight line in relation to the central row of the Doric Temple, it is $12.49 \mathrm{pm}$ (11.49 am in solar time) and this star is far above. And what happens then is that inside the Doric Temple, the sunrays do not enter anywhere; and in the attics of the Porter's Lodge, there is not any slight sunray reflected on the walls. On the contrary, on the Dragon Stair-way and on the Nature Square the sunlight falls vertically, shining on the white trencadís and filling the space with a dazzling light. In other words: at that moment, there is a great contrast between light and darkness, but with the first dominating the second.

Now, whoever contemplates this after having done all the steps indicated, when strolling through the square and perceiving the sunlight falling around him, will also experience how "the other light" revives in his interior, extending in every corner of his soul... And then the last question will blur: certainly, the second solar medallion of the central row represents the summer sun, but when it is at its zenith, producing the maximum illumination and signifying the inner star that will never set anymore.

The fact that this happens on 23 June, when Christians celebrate the birth of John the Baptist, probably had a symbolic meaning for Antoni Gaudí: that this prophet, with his works, knew how to turn darkness into light, thus anticipating eternal life. In Park Güell, there is not any direct reference to this figure; but, in my opinion, there is a portrait of anyone who has followed the steps indicated in the work: this is the being that in the vertical medallion of the stairway emerges from the shield of Catalonia as if it were from the bowels of the Earth; the being that leaves the park feeling himself to be reborn; in a nutshell, the genuine representative of the Renaixença.

\section{Final remarks}

Lastly, I would like to recap the main data that have been presented in this paper, and point out some consequences. From 1898 onwards, Antoni Gaudí constructed mainly two works by means of aesthetic geometry: Casa Bellesguard and Park Güell. And we can say that if the first building was made to rediscover the relationship between his architecture and the aesthetic geometry of Peter Lenz, the second one shows the possibilities of 
unfolding this type of geometry. But the project went beyond that: other artists also built constructions with aesthetic geometry, which referred to the symbolic core of Park Güell: the imaginary Temple of Solomon. All these buildings were erected while Gaudí was professionally active, and were made either by him or by an architect that had some kind of personal relationship to him. And around 1916, Gaudí synthesized all this work in the image painted on that rock located at the highest part of the park.

As this project was carried out, a group of people from various professions was formed. And, to my knowledge, the people involved in this project were the following. As architects or building masters: Antoni Gaudi, Lluís Domènech i Montaner, Bernardí Martorell i Puig, Camil Oliveras Gensana, Josep Domènech i Estepà, Jaume Brossa Mascaró, Francesc Berenguer, Joan Rubió i Bellver, Josep Maria Jujol, and Domènech Sugranyes. And as businessmen: Eusebi Güell i Bacigalupi, Lluís MartíCodolar, and members of the Gil i Serra family. These were the people that formed the lodge represented in the set of the sloping portico of Park Güell. As members of this group, they had the objective of promoting a kind of art that, like the brotherhoods of Saint Luke that emerged at the end of medieval times and reappeared in the late $18^{\text {th }}$ century, would encourage a kind of cohabitation driven by the values of the first Christian communities.

At this point, we can wonder if the final objective of all this work with such religious symbolism, really was the construction of a mere urbanization; or if it was not also linked to the religious work par excellence of Gaudí, namely the Temple de la Sagrada Família. In this sense, the first thing that can be verified is that the square that frames the key of God in Park Güell, measures the same as the square that forms the crossing in the Sagrada Familia, i.e., around $16 \mathrm{~m}$ by $16 \mathrm{~m}$. And if from the centre of this crossing we develop the same geometric process that we have applied in Park Güell, we will see that in this case the lines drawn do pass through sites of the Basilica that justify such application. In this way, the symbolic meaning that we have discovered in Park Güell would be present in the Sagrada Familia: the centre of the tower of the Virgin Mary would also represent the Inner Room of the Temple of Solomon, and the centre of the tower of Jesus Christ would symbolize the altar of the burnt offering. Likewise, the relation between light and artistic work, which in Park Güell predominantly expresses a movement from top to bottom, in the Sagrada Familia would also express a movement bottom-up, culminating in the four-armed cross that will have to crown the tower of Jesus Christ, a symbol of the resurrection of the dead. Moreover, there is another element that 
would show the close relationship between these two works: it turns out that the transmuted rock of Park Güell is at the same height above sea level, as the height that one day the four-armed cross of the Sagrada Familia will have. Therefore, Gaudí could have painted the green cross of the transmuted rock also as a proactive representation of the four-armed cross of the Temple de la Sagrada Família. By the way, a cross whose arms should also be oriented to the four cardinal points.

Carles Rius Santamaria

Universitat de Barcelona

carlesrius@ub.edu 
Park Güell: Reconstructing the Temple of Jerusalem through Light and Aesthetic Geometry

Having found that some important issues about Park Güell remain to be resolved, this article analyses the construction in detail, identifying a set of stones that symbolize a lodge aimed at making works of art through aesthetic geometry. With these works, the members of this group wanted to foster a kind of society based on the values of the first Christian communities. The study of the relationship between sunlight and some parts of the park allows us to locate a representation of the Temple of Jerusalem in it, conceived with such geometry. In this way, Park Güell is revealed as the symbolic foundation on which the Temple de la Sagrada Familia should be erected.

Keywords: Park Güell, lodge, aesthetic geometry, light, Temple of Jerusalem, Sagrada Família

El parc Güell: Reconstruir el Temple de Jerusalem per mitjà de La llum I DE LA GEOMETRIA ESTÈTICA

Després d'haver constatat que sobre el parc Güell encara hi ha qüestions importants per resoldre, aquest article analitza en detall la construcció i hi identifica un conjunt de pedres que simbolitza una lògia que pretenia fer obres d'art mitjançant la geometria estètica. Amb aquests treballs, els membres del grup volien fomentar un tipus de societat basada en els valors de les primeres comunitats cristianes. L'estudi de la relació entre la llum del sol i algunes parts del parc ens permetrà localitzar-hi una representació del Temple de Jerusalem concebuda amb tal geometria. D'aquesta manera, el parc Güell es revela com el fonament simbòlic a sobre del qual s'hauria d'erigir el temple de la Sagrada Família.

Paraules clau: Parc Güell, lògia, geometria estètica, Ilum, Temple de Jerusalem, Sagrada Família 
Aquest article ha estat publicat originalment a Matèria. Revista internacional d'Art (ISSN en línia: 2385-3387)

Este artículo ha sido publicado originalmente en Matèria. Revista internacional d'Art (ISSN en línea: 2385-3387)

This article was originally published in Matèria. Revista internacional d'Art (Online IS S N : 2385-3387)

\section{MATÈRIA}

Revista internacional d'Art

Els autors conserven els drets d'autoria i atorguen a la revista el dret de primera publicació de l'obra.

Els textos es difondran amb la llicència de Reconeixement-NoComercialSenseObraDerivada de Creative Commons, la qual permet compartir I'obra amb tercers, sempre que en reconeguin I'autoria, la publicació inicial en aquesta revista i les condicions de la llicència: https://creativecommons. org/licenses/by-nc-nd/4.0/deed.ca

Los autores conservan los derechos de autoría y otorgan a la revista el derecho de primera publicación de la obra.

Los textos se difundirán con la licencia de Atribución-NoComercial-SinDerivadas de Creative Commons que permite compartir la obra con terceros, siempre que éstos reconozcan su autoría, su publicación inicial en esta revista y las condiciones de la licencia: https://creativecommons.org/licenses/ by-nc-nd/4.0/deed.es

The authors retain copyright and grant the journal the right of first publication.

The texts will be published under a Creative Commons Attribution-NonCommercial-NoDerivatives License that allows others to share the work, provided they include an acknowledgement of the work's authorship, its initial publication in this journal and the terms of the license: https://creativecommons.org/licenses/by-nc-nd/4.0/deed.en

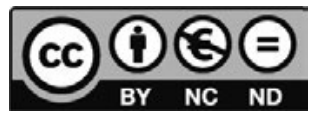

